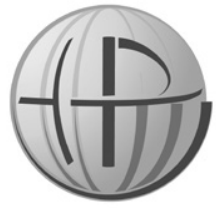

Horyzonty Polityki 2020, Vol. 11, No 36

\section{Agnieszka Parkitna}

http://orcid.org/0000-0003-2378-4007 Akademia Ignatianum w Krakowie Instytut Nauk o Polityce i Administracji agnieszka.parkitna@student.ignatianum.edu.pl

DOI: $10.35765 / H P .1948$

\title{
Konstytucyjne możliwości ograniczania praw i wolności człowieka i obywatela w stanach nadzwyczajnych a rozwiązania przyjęte $w$ Polsce $w$ trakcie pandemii COVID-19
}

\section{Streszczenie}

CEL NAUKOWY: Artykuł ma na celu przedstawienie w skrótowej formie możliwości ograniczania wolności i praw człowieka i obywatela w stanach nadzwyczajnych w ujęciu Konstytucji RP z 1997 roku, a następnie zestawienie z nimi rozwiązań przyjętych w Polsce $w$ trakcie pandemii COVID-19 oraz próba oceny konstytucyjności tychże regulacji.

PROBLEM I METODY BADAWCZE: Wywód opiera się na analizie treści rozwiązań konstytucyjnych, limitujących możliwość ograniczania praw i wolności. Poddaje również analizie i ocenie prawnej unormowania przyjęte przez rządzących w czasie pandemii.

PROCES WYWODU: Rozważania mają dwudzielną strukturę - w pierwszej części na podstawie ustawy zasadniczej i literatury przedmiotu omówiono konstytucyjne możliwości ograniczania praw i wolności w stanach nadzwyczajnych. W drugiej części omówiono ograniczenia praw i wolności wprowadzone w Polsce podczas pandemii, a także podjęto próbę ich krytycznej analizy względem zgodności z Konstytucją.

WYNIKI ANALIZY NAUKOWEJ: Chociaż polska ustawa zasadnicza precyzyjnie określa zasady i możliwości ograniczenia praw i wolności w stanach nadzwyczajnych, to jej unormowania nie znalazły zastosowania w praktyce. 
Akty normatywne, które wprowadzały ograniczenia w czasie pandemii, budzą bardzo poważne zastrzeżenia z punktu widzenia ich konstytucyjności.

WNIOSKI, INNOWACJE, REKOMENDACJE: Przepisy ograniczające prawa i wolności $\mathrm{w}$ trakcie pandemii nie tylko łamią zasady systemu prawnego i zwiększają chaos legislacyjny, ale także podważają zaufanie obywateli względem prawa. Wielu ukarano za nieprzestrzeganie niekonstytucyjnych ograniczeń, istnieje zatem ryzyko, że nastąpi szereg pozwów przeciw państwu o odszkodowania. Polskie społeczeństwo postpandemiczne może zatem nie być tak samo pewne jak niegdyś nienaruszalności praw i wolności gwarantowanych ustawą zasadniczą.

\title{
SŁowA KLUCzowe:
}

konstytucja, pandemia, stany nadzwyczajne, ograniczenie praw i wolności

\author{
Abstract \\ CONSTITUTIONAL POSSIBILITIES OF LIMITING \\ HUMAN AND CIVIL RIGHTS AND FREEDOMS \\ IN STATES OF EMERGENCY VERSUS \\ REGULATIONS ESTABLISHED IN POLAND DURING \\ THE COVID-19 PANDEMIC
}

RESEARCH OBJECTIVE: The aim of the article is to present in abbreviated form the possibility of limiting the freedoms as well as human and citizen rights in states of emergency according to the Constitution of the Republic of Poland published in 1997, to compare the possibilities with the solutions established in Poland during the COVID-19 pandemic and finally to assess the constitutionality of these regulations.

THE RESEARCH PROBLEM AND METHODS: The arguments are based on content analysis of constitutional solutions which give the possibility to limit citizens' rights and freedoms. It also analyses and legally evaluates the regulations adopted by the government during the pandemic.

THE PROCESS OF ARGUMENTATION: The considerations have a twofold structure - the first part presents constitutional possibilities of limiting rights and freedoms in states of emergency based on the Constitution and subject literature. The second part discusses the restrictions on rights and freedoms established in Poland during the pandemic, with an attempt to critically analyse them in terms of compatibility with the Constitution. 
Konstytucyjne możliwości ograniczania praw i wolności człowieka

RESEARCH RESULTS: Although the Polish Constitution precisely defines the rules and possibilities of limiting the rights and freedoms in states of emergency, its regulations have not been applied in practice. Normative acts which were introducing restrictions during the pandemic raise very serious reservations from the point of view of their constitutionality.

CONCLUSIONS, INNOVATIONS, AND RECOMMENDATIONS: Laws limiting rights and freedoms during the pandemic not only break the rules of the legal system and increase legislative chaos but also undermine citizens' trust in the law. A lot of people have been fined for not respecting unconstitutional restrictions which, as a result, might lead to a series of claims for damages against the state. Therefore, Polish post-pandemic society may no longer be as sure of the inviolability of the rights and freedoms guaranteed by the Constitution as in the past.

\section{KeYwORDS:}

Costitution, Pandemic, Limiting Rights and Freedoms, States of Emergency

\section{WSTĘP}

Kiedy wiosną 2020 roku Światowa Organizacja Zdrowia (World Health Organization; dalej: WHO) ogłosiła pandemię nowego wirusa (tzw. koronawirusa lub COVID-19), kolejne państwa zaczęły wprowadzać swoje konstytucyjne odpowiedniki stanów nadzwyczajnych lub zaostrzać przepisy w taki sposób, aby możliwe było ograniczanie praw i wolności jednostek na rzecz zadbania o bezpieczeństwo w kraju. Chociaż Konstytucja Rzeczypospolitej Polskiej z 2 kwietnia 1997 roku (Dz. U. z 1997 r., nr 78, poz. 483; dalej: Konstytucja) przewiduje instytucję stanów nadzwyczajnych, wśród których wyróżnia: stan wojenny, stan wyjątkowy i stan klęski żywiołowej (Konstytucja, art. 228), to jednak żaden $\mathrm{z}$ nich nie został dotychczas ogłoszony. Zamiast tego wprowadzono obostrzenia ograniczające prawa i wolności człowieka i obywatela w drodze uchwalenia nowych aktów normatywnych bądź zmian do już istniejących, co spotkało się z negatywną oceną konstytucyjności takich rozwiązań m.in. ze strony Rzecznika Praw Obywatelskich (dalej: RPO) Adama Bodnara i części środowiska prawniczego. Niniejszy artykuł ma na celu syntetyczne przedstawienie tej problematyki poprzez analizę treści rozwiązań 
konstytucyjnych odnośnie do możliwości ograniczania praw i wolności człowieka i obywatela w stanach nadzwyczajnych, omówienie zasad ogólnych tychże na podstawie literatury przedmiotu, a także krytyczną analizę pod kątem konstytucyjności wprowadzania obostrzeń przez decydentów podczas pandemii. Celem zawężenia obszaru wywodu pominięto ustawy szczegółowe z 2002 roku, dotyczące poszczególnych stanów nadzwyczajnych oraz ustawę o wyrównywaniu strat majątkowych wynikających z ograniczenia w czasie stanu nadzwyczajnego wolności i praw człowieka i obywatela.

\section{KONSTYTUCYJNE MOŻLIWOŚCI OGRANICZANIA PRAW I WOLNOŚCI CZŁOWIEKA I OBYWATELA}

Polska ustawa zasadnicza, zgodnie z demokratycznym charakterem państwa i zobowiązaniami wynikającymi z podpisanych przez Rzeczpospolitą umów międzynarodowych, stoi na straży ochrony praw i wolności człowieka i obywatela. W związku z tym ograniczenia dotyczące tychże mogą być ustanawiane jedynie w drodze wyjątku i są obostrzone koniecznością spełnienia określonych warunków. Określa je art. 31 ust. 3 Konstytucji i mogą zatem zostać ustanowione wyłącznie w drodze ustawy, a nie akcie niższego rzędu, oraz muszą być konieczne z punktu widzenia ochrony jednej z wartości określonych w zamkniętym katalogu, tj. bezpieczeństwa państwa, jego porządku publicznego, środowiska, zdrowia lub moralności publicznej, a także praw i wolności innych osób. Przy tym wszystkim bardzo istotnym jest, iż ",ograniczenia te nie mogą naruszać istoty wolności i praw" (Konstytucja, art. 31 ust. 3). Powinny być zatem nadal realizowane, pomimo ich zawężenia, $w$ duchu wartości, jakie stały za ich wprowadzeniem. Konieczne jest przy tym, aby wprowadzane ograniczenia były zgodne z zasadą proporcjonalności, a więc ich ustanowienie rzeczywiście służyło ochronie zagrożonych wartości (zasada przydatności), aby dokonano wyboru najmniej uciążliwych dla jednostki środków (zasada konieczności) oraz aby zachodziła korelacja proporcjonalności między uciążliwością wprowadzanych ograniczeń a spełnianiem celu, jakim jest ochrona danej wartości (Sarnecki, 2008, s. 99). Co więcej, ograniczenia takowe nie mogą stać w sprzeczności z zasadą demokratycznego państwa prawnego 
(Konstytucja, art. 2), lecz powinny być interpretowane w jej duchu przy korzystaniu z zasady proporcjonalności, ze szczególnym zwróceniem uwagi na zachowanie praw mniejszości oraz swobody działania opozycji (Sarnecki, 2008, s. 100).

Powyższe generalne unormowania konstytucyjne, dotyczące ograniczania praw i wolności człowieka i obywatela, odnoszą się do sytuacji normalnego funkcjonowania państwa. Inaczej ma się jednakże sprawa w sytuacjach szczególnego zagrożenia, gdy istnieje możliwość zawieszania praw i wolności po wprowadzeniu jednego ze stanów nadzwyczajnych. Ustawa zasadnicza przewiduje trzy takowe: stan wojenny, stan wyjątkowy i stan klęski żywiołowej (Konstytucja, art. 228 ust. 1), przy czym możliwość ich wprowadzenia jest zależna od źródła powstania zagrożenia, które wymaga podjęcia nadzwyczajnych rozwiązań. W przypadku stanu wojennego jest to kwestia zagrożenia zewnętrznego państwa, zbrojnej napaści na kraj lub wspólnej obrony wynikającej ze zobowiązań sojuszniczych (Konstytucja, art. 229), w przypadku stanu wyjątkowego wewnętrznego zagrożenia ustroju kraju, porządku publicznego lub bezpieczeństwa jego obywateli (Konstytucja, art. 230 ust. 1), w przypadku zaś stanu klęski żywiołowej wystąpienie katastrof naturalnych lub awarii technicznych, a konkretnie zapobieżenie bądź usunięcie ich skutków (Konstytucja, art. 232). Na podstawie Rozdziału XI Konstytucji odnośnie do stanów nadzwyczajnych można wskazać szczegółowo różnice pomiędzy poszczególnymi z nich, jak chociażby sposób wprowadzenia (stan wojenny i wyjątkowy wprowadzany przez Prezydenta na wniosek Rady Ministrów, stan klęski żywiołowej przez Radę Ministrów), czy też długość trwania i możliwość przedłużenia. Na użytek niniejszych rozważań istotniejszy jest jednak katalog praw i wolności człowieka i obywatela, jakie mogą być ograniczane w poszczególnych stanach nadzwyczajnych.

W przypadku stanu wojennego i wyjątkowego ustawodawca przyjął technikę negatywną względem określenia, jakie prawa i wolności mogą być ograniczane i w związku z tym wymienia te, które ograniczeniom podlegać nie moga tj. godność człowieka, obywatelstwo, ochrona życia, humanitarne traktowanie, ponoszenie odpowiedzialności karnej, prawo do sądu, dobra osobiste, sumienie i religia, petycje oraz rodzina i dziecko (Konstytucja, art. 233 ust. 1). Odmienny charakter ma regulacja odnosząca się do stanu klęski 
żywiołowej, gdzie przyjęto technikę pozytywną zakreślenia wolności i praw - ograniczeniu podlegać mogą zatem: wolność działalności gospodarczej, wolność osobista, nienaruszalność mieszkania, wolność pobytu i poruszania się po terytorium Rzeczypospolitej Polskiej, prawo do strajku, prawo własności, wolność pracy, prawo do bezpiecznych i higienicznych warunków pracy oraz prawo do wypoczynku (Konstytucja, art. 233 ust. 3). Ze względu na samą technikę przyjętą przez ustawodawcę przy wymienianiu ograniczanych praw i wolności należy stwierdzić, że stan klęski żywiołowej rodzi mniejsze konsekwencje prawne i jest korzystniejszy z punktu widzenia zachowania swobody jednostki (Prokop, 2005, s. 103). Warto również zaznaczyć, że niezależnie od pozostałych przepisów limitacyjnych ustawa zasadnicza zawiera również gwarancję, iż prawa i wolności człowieka w żadnej sytuacji nie będą ograniczane „,wyłącznie z powodu rasy, płci, języka, wyznania lub jego braku, pochodzenia społecznego, urodzenia oraz majątku" (Konstytucja, art. 233 ust. 2). Z pewnością należy ocenić pozytywnie taki zapis jako zgodny z zasadą demokratycznego państwa prawnego i standardami prawa międzynarodowego $\mathrm{w}$ dziedzinie ochrony praw człowieka.

Rozważając problematykę ograniczania praw i wolności w stanach nadzwyczajnych, nie sposób pominąć art. 288 Konstytucji, który zawiera zasady ogólne, odnoszące się do wszystkich trzech z nich. Na pierwszy plan wysuwa się zawarta w nim zasada wyjątkowości, która wskazuje na to, że poza spełnieniem przesłanek typowych dla każdego ze stanów nadzwyczajnych muszą też zaistnieć warunki ogólne: musi łącznie dojść do sytuacji wystąpienia szczególnego zagrożenia oraz niewystarczalności środków konstytucyjnych. To, czy dane warunki spełniają owe przesłanki, ma niewątpliwie charakter ocenny i należy każdorazowo do organu, który wprowadza dany stan nadzwyczajny. Niemniej jednak z pewnością musi wystąpić zagrożenie realne, obiektywnie możliwe do stwierdzenia i godzące $\mathrm{w}$ bezpieczeństwo państwa, a użycie normalnie obowiązujących na gruncie Konstytucji unormowań nie będzie wystarczające (Prokop, 2005, s. 18-23). Przepisy te zatem znacznie zawężają spektrum sytuacji, w których wprowadzenie stanu nadzwyczajnego może nastąpić, a tym samym zmniejszają ryzyko nieuzasadnionego ograniczania praw i wolności jednostek.

Równie istotna jest zasada legalności - stany nadzwyczajne mogą być bowiem wprowadzone ,tylko na podstawie ustawy, w drodze 
rozporządzenia, które podlega dodatkowemu podaniu do publicznej wiadomości” (Konstytucja, art. 228 ust. 2), „zakres, w jakim mogą zostać ograniczone wolności i prawa człowieka i obywatela w czasie poszczególnych stanów nadzwyczajnych określa ustawa" (Konstytucja, art. 228 ust. 3), jak również ustawa „może określić podstawy, zakres i tryb wyrównywania strat majątkowych, wynikających z ograniczenia w czasie stanu nadzwyczajnego wolności i praw człowieka i obywatela" (Konstytucja, art. 228 ust. 4). Warto zauważyć, że wprowadzono trójpoziomową strukturę związaną z uregulowaniem stanów nadzwyczajnych: pierwszym, najbardziej ogólnym poziomem jest Konstytucja, drugim - ustawy szczegółowe o stanach nadzwyczajnych, a trzecim - rozporządzenie wprowadzające sam stan nadzwyczajny w życie, które ma dość wyjątkowy charakter, gdyż jest wydawane nie z upoważnienia ustawy, lecz Konstytucji; ma ono na celu nie tylko uruchomienie procedury wprowadzania stanu nadzwyczajnego, ale m.in. również określenie, które z przepisów ustawy szczegółowej znajdą w tym wypadku zastosowanie (również w kwestii ograniczania praw i wolności), a także, jaki jest powód, data ogłoszenia, czas obowiązywania i zasięg terytorialny stanu nadzwyczajnego (Prokop, 2005, s. 23-30). Stąd też ustawa zasadnicza uznała za konieczne zaznaczyć, że niezbędne jest podanie treści rozporządzenia do wiadomości publicznej, aby wszyscy na danym terytorium mieli możliwość się z nim zapoznać i powziąć wiedzę na temat tego, jakie prawa i wolności, w jakim zakresie i na jak długi okres zostaną ograniczone.

Ustawodawca tworząc zapisy odnoszące się do stanów nadzwyczajnych nie zapomniał rzecz jasna o odwołaniu do zasady proporcjonalności. Kładzie bowiem nacisk na to, aby skala podjętych działań była odpowiednia do zaistniałych zagrożeń (Konstytucja, art. 288 ust. 5). Zasadę tę można w takim wypadku odnosić szerzej także do samego procesu decyzyjnego związanego $\mathrm{z}$ wprowadzaniem stanu nadzwyczajnego, działań organów władzy w czasie jego trwania czy też późniejszej odpowiedzialności osób go wprowadzających lub podczas oceny konstytucyjności przyjmowanych podczas niego rozwiązań (Prokop, 2005, s. 31-32). Obok zasady proporcjonalności ustawodawca porusza również zasadę celowości, zgodnie z którą podejmowane działania mają prowadzić do możliwie jak najszybszego powrotu do normalnego trybu funkcjonowania państwa 
(Konstytucja, art. 288 ust. 5). Decydenci powinni zatem stale zmierzać do celu, jakim jest zakończenie stanu nadzwyczajnego, przy czym należy założyć, że powinno to nastąpić przy jednoczesnym respektowaniu i nadaniu prymatu zasadzie proporcjonalności w razie wystąpienia konfliktu między tymi wartościami, aby dla szybszego zażegnania szczególnego zagrożenia nie doszło do naruszenia głębiej praw i wolności (Prokop, 2005, s. 33-35).

Warto uwzględnić, że Konstytucja przewiduje zasadę ochrony podstaw systemu prawnego, nie dopuszczając w czasie stanu nadzwyczajnego do zmiany Konstytucji, ordynacji wyborczych, ustawy o wyborze prezydenta i ustaw szczegółowych dotyczących stanów nadzwyczajnych (Konstytucja, art. 288 ust. 6), a także zasadę ochrony organów przedstawicielskich, która odpowiednio wydłużając kadencje poszczególnych organów władzy nie pozwala na przeprowadzenie w trakcie trwania stanu nadzwyczajnego ani $90 \mathrm{dni}$ po jego ustaniu referendum ogólnokrajowego, wyborów parlamentarnych i prezydenckich, a także uniemożliwia skrócenie kadencji Sejmu oraz dozwala na przeprowadzenie wyborów samorządowych tylko na terytorium, gdzie nie wprowadzono stanu nadzwyczajnego (Konstytucja, art. 288 ust. 7). Rozwiązania te służyć mają zachowaniu stabilności ustroju i systemu państwa, zapewnieniu ciągłości władzy pomimo istnienia sytuacji szczególnego zagrożenia oraz uchronieniu jednostek przed poszerzaniem ograniczeń ich praw i wolności. Jak można zauważyć, każde wprowadzenie stanu nadzwyczajnego skutkuje również koniecznością odłożenia wyborów, które miałyby się odbyć planowo w czasie jego trwania. Jest to zatem zasada mająca na celu ochronę demokratycznego porządku prawnego państwa w sytuacji, kiedy może on zostać zagrożony, jednakże może też stwarzać okazję do nadużyć ze strony decydentów, którzy mogliby w celu utrzymania się u władzy, np. znacząco wydłużyć czas obowiązywania stanu klęski żywiołowej (Prokop, 2005, s. 35-43).

Oceniając przekrojowo powyższe unormowania odnoszące się do stanów nadzwyczajnych, należy stwierdzić, że mogą one skutecznie przyczynić się do uniknięcia nieuzasadnionego lub nadmiernego ograniczania praw i wolności w przypadku wystąpienia szczególnych zagrożeń dla bezpieczeństwa państwa. Ustawa zasadnicza dostarcza zatem spójnych i możliwych do zastosowania w praktyce rozwiązań, w razie gdyby taka szczególna sytuacja się pojawiła. 


\section{ROZWIAZZANIA PRAWNE PRZYJĘTE W POLSCE PODCZAS PANDEMII COVID-19 W KONTEKŚCIE UNORMOWAŃ KONSTYTUCYJNYCH}

Jak już wspominano w niniejszym wywodzie - w marcu 2020 roku WHO ogłosiła stan pandemii wirusa COVID-19 (tzw. koronawirusa), po tym jak w ciągu kilku miesięcy choroba zdołała się rozprzestrzenić z Chin do 110 krajów świata. Szef organizacji wskazał, że jej przedstawiciele są zaniepokojeni brakiem podejmowania przez rządy poszczególnych krajów działań zapobiegawczych w tej kwestii, gdyż były rekomendowane (WHO, 2020). W reakcji zarówno na tę wypowiedź, jak i dynamicznie rozwijającą się sytuację epidemiologiczną kolejne kraje zaczęły podejmować mniej lub bardziej zdecydowane działania, kilka spośród nich uciekło się również do wprowadzenia swoich odpowiedników stanów nadzwyczajnych.

Chociaż z pewnością wielu obywateli Rzeczypospolitej zaznajomionych z treścią ustawy zasadniczej sądziło, iż nastąpi to również w Polsce, to sprawy przybrały zgoła inny obrót. Pomimo tego, że środki konstytucyjne mogłyby nie być wystarczające do zapobieżenia rozprzestrzenianiu się pandemii ze względu na konieczną głębokość ingerencji w prawa i wolności człowieka i obywatela, nie doszło do ogłoszenia stanu nadzwyczajnego (w tym wypadku byłby to stan klęski żywiołowej). Zamiast tego uchwalono ustawę o szczególnych rozwiązaniach związanych z zapobieganiem, przeciwdziałaniem i zwalczaniem COVID-19, innych chorób zakaźnych oraz wywołanych nimi sytuacji kryzysowych (Dz. U. z 2020 r., poz. 374), która zmieniała ustawę z 2008 roku o zapobieganiu oraz zwalczaniu zakażeń i chorób zakaźnych u ludzi (Dz. U. z 2019 r., poz. 1239 ze zm.), a także rozporządzenie w sprawie ogłoszenia na obszarze Rzeczypospolitej Polskiej stanu epidemii (Dz. U. z 2020 r., poz. 491, poz. 522, poz. 531) i inne akty o randze rozporządzeń, wprowadzające nakazy i zakazy w związku z zaistniałą sytuacją.

Rozwiązanie tej szczególnej sytuacji faktycznej w opisanej powyżej drodze normatywnej, niejako z pominięciem wprowadzania stanu nadzwyczajnego, rodzi znaczące wątpliwości z punktu widzenia zgodności takiego postępowania z Konstytucją, zwłaszcza w kontekście ograniczania praw i wolności człowieka i obywatela. Zwrócił na to uwagę m.in. RPO Adam Bodnar, który wystosował pismo do 
premiera Mateusza Morawieckiego w tej sprawie, zwracając uwagę na szereg możliwych do dostrzeżenia nieprawidłowości (Bodnar, 2020). Warto jednakże w tym miejscu dokonać szczegółowej analizy poszczególnych obostrzeń, które mogą budzić wątpliwości z punktu widzenia konstytucyjnych ram odnoszących się do ograniczania praw i wolności.

Jednym z takich dyskusyjnych przepisów był zakaz przemieszczania się. Zgodnie ze wspomnianą ustawą o zapobieganiu oraz zwalczaniu zakażeń i chorób zakaźnych minister właściwy do spraw zdrowia ma uprawnienie do uregulowania $\mathrm{w}$ drodze rozporządzenia „,czasowego ograniczenia określonego sposobu przemieszczania się" (Dz. U. z 2019 r., poz. 1239 ze zm.) - nie jest jednak władny wprowadzić zakazu przemieszczania się w ogóle, co miało miejsce; co istotne, nawet Rada Ministrów ma wedle ustawy wyłącznie uprawnienie względem „wprowadzenia nakazu określonego sposobu przemieszczania się, a nie zakazu przemieszczania się" (Bodnar, 2020, s. 2-4). Pomimo tego ów zakaz przemieszczania się został powtórzony następnie w Rozporządzeniu Rady Ministrów z dnia 31 marca 2020 r. (Dz. U. z 2020 r., poz. 566). Warto zaznaczyć tutaj, że stanowił on o zakazie przemieszczania się osób na terytorium Rzeczypospolitej poza wyznaczonymi celami, zawężonymi do czynności zawodowych, zaspokajania niezbędnych potrzeb życia codziennego, działalności wolontaryjnej dla przeciwdziałania pandemii, brania udziału w czynnościach kultu religijnego oraz działań na rzecz ochrony zwierząt. De facto zatem przepis ów stał w sprzeczności z prawem do swobodnego przemieszczania się po terytorium Rzeczypospolitej (Konstytucja, art. 52 ust. 1). Jako że został wprowadzony na mocy rozporządzenia, to nie zgadzał się również $\mathrm{z}$ nadrzędną podczas normalnego trybu funkcjonowania państwa klauzulą wprowadzania ograniczeń praw i wolności wyłącznie w ustawie (Konstytucja, art. 31 ust. 3).

Dość podobnie wyglądała kwestia wprowadzenia obowiązku przebywania na kwarantannie osób zdrowych, które były narażone na zakażenie. Chcąc odwołać się do konstytucyjnego katalogu praw i wolności, należy wskazać, że ograniczone zostało tutaj ponownie prawo do swobodnego przemieszczania się po terytorium kraju (Konstytucja, art. 52 ust. 1) oraz wolność osobista (Konstytucja, art. 41 ust. 1). Ów nakaz poddania się kwarantannie również został wprowadzony we wspominanym rozporządzeniu w sprawie ogłoszenia 
Konstytucyjne możliwości ograniczania praw i wolności człowieka

stanu epidemii (Dz. U. z 2020 r., poz. 491, poz. 522, poz. 531), choć kompetencje w tej sprawie miała wyłącznie Rada Ministrów i co za tym idzie przekroczone zostały ramy upoważnienia ustawowego, a tym samym wspomniane ograniczenia praw i wolności człowieka i obywatela ponownie zostały wprowadzone aktem niższym aniżeli ustawa, łamiąc generalną zasadę konstytucyjną (Bodnar, 2020, s. 5-7).

Kolejną wartą poruszenia kwestią są ograniczenia w zakresie uprawiania kultu religijnego. Zostały one również wprowadzone na mocy wspominanego rozporządzenia w sprawie ogłoszenia stanu epidemii (Dz. U. z 2020 r., poz. 491, poz. 522, poz. 531), przy czym warto dodać, że obejmowało ono nie tylko praktykowanie kultu religijnego w miejscach publicznych, ale również w przeznaczonych do tego obiektach i budynkach poprzez ograniczenie liczby uczestników obrzędów - z początku do 50 osób, a następnie do 5 osób. Należy tutaj zauważyć, że przepisy te ingerują bezpośrednio w sferę wolności religii - składa się bowiem na nią nie tylko wolność wyznawania bądź przyjmowania religii wedle własnego wyboru, ale również możliwość jej uzewnętrzniania, nie tylko w formie indywidualnej, ale także zbiorowej przez wspólną modlitwę, uczestnictwo w obrzędach, praktykowanie etc. (Konstytucja, art. 53 ust. 2). W tym przypadku ustawa zasadnicza zdecydowała się dodatkowo podkreślić, że wolność ta może być ograniczana ,jedynie w drodze ustawy i tylko wtedy, gdy jest to konieczne do ochrony bezpieczeństwa państwa, porządku publicznego, zdrowia, moralności lub wolności i praw innych osób" (Konstytucja, art. 53 ust. 5). I o ile w rozważanej sytuacji faktycznej można znaleźć podstawy dla wprowadzania ograniczeń w tym względzie poprzez spełnienie przesłanki ochrony zdrowia, to ogłoszone ograniczenie wolności uzewnętrzniania religii nie nastąpiło w ustawie. Raczej nie sposób bowiem uznać, że szerokie upoważnienie z ustawy o zapobieganiu oraz zwalczaniu zakażeń i chorób zakaźnych u ludzi (Dz. U. z 2019 r., poz. 1239 ze zm., art. 46 ust. 4 pkt. 4), uprawniające ministra właściwego do spraw zdrowia do określenia zakazu organizowania innych zgromadzeń ludności mogłoby być wystarczające do tego, aby ograniczać konstytucyjną wolność uzewnętrzniania religii (Bodnar, 2020, s. 7-9). Ponownie zatem należy poddać krytyce podjęte rozwiązania normatywne jako uchwalone w sprzeczności z założeniami konstytucyjnymi. Co warto 
zaznaczyć - nawet w ustawach szczególnych odnoszących się do konkretnych stanów nadzwyczajnych ustawodawca nie zdecydował się na wprowadzanie ograniczeń sumienia i religii bądź limitowanie zgromadzeń religijnych (Machowicz, 2009, s. 74), tym bardziej zatem zwraca uwagę wprowadzenie przez decydentów tak daleko idących obostrzeń w normalnym stanie funkcjonowania państwa.

$Z$ bodaj największym wzburzeniem społeczeństwa spotkał się zakaz wstępu do lasów i parków narodowych, wdrożony na prośbę premiera przez Lasy Państwowe i podany do wiadomości przez ministerstwo środowiska. W dobie wprowadzania kolejnych ograniczeń naród odebrał to jako zamach na prawo do wypoczynku (Konstytucja, art. 66 ust. 2). Warto wspomnieć, że również to obostrzenie zostało wprowadzone niezgodnie z obowiązującymi normami prawnymi. Zgodnie bowiem z treścią ustawy o lasach (Dz. U. z 1991 r. nr 101, poz. 444, art. 26 ust. 3) istnieje enumeratywnie określony katalog przyczyn, z powodu których nadleśniczy może zarządzić zakaz wstępu do lasów (m.in. zagrożenie pożarowe), nie obejmuje on jednakże kwestii wiążących się z zaistniałą sytuacją. Należy zatem skonstatować, że ów zakaz był wprowadzony przy braku jakiejkolwiek podstawy prawnej; wobec oporu społeczeństwa decydenci jednakże szybko się z tej decyzji wycofali.

Poważne wątpliwości rodzi również zakaz zgromadzeń, który został wprowadzony na mocy wspomnianego po wielokroć rozporządzenia wprowadzającego stan epidemii. Umocowanie w ustawie o zapobieganiu oraz zwalczaniu zakażeń i chorób zakaźnych u ludzi pozwalało bowiem na dookreślenie w akcie niższego rzędu "zakazu organizowania widowisk i innych zgromadzeń ludności” (Dz. U. z 2019 r., poz. 1239 ze zm., art. 46 ust. 4 pkt. 4). Niemniej jednak powstaje pytanie, czy z punktu widzenia zasady proporcjonalności możliwe było wprowadzenie zakazu zgromadzeń. W końcu bowiem nawet jeśli dane prawo czy wolność są ograniczane, to nie powinny zostać obywatelom całkowicie odebrane, zwłaszcza w normalnym trybie funkcjonowania państwa, kiedy nie wprowadzono stanu nadzwyczajnego. Dokonując krytycznej analizy należy zatem zastanowić się, czy tak wprowadzone obostrzenie nie stoi w sprzeczności ze wskazaniem, że „Ograniczenia te nie mogą naruszać istoty wolności i praw” (Konstytucja, art. 31 ust. 3). Aby zbadać, czy tak się wydarzyło, należy zastanowić się zatem, czy prawo to jest w dalszym 
ciągu możliwe do realizacji, czy bronione są wartości, jakie stały za jego wprowadzeniem i czy nadal pełni ono swoje funkcje (Sarnecki, 2008, s. 100). Nie sposób odpowiedzieć twierdząco - prawo nie zostało bowiem poddane ograniczeniom, dostosowującym możliwość organizowania zgromadzeń publicznych do realiów pandemii, lecz zniesione.

Uchybień można doszukać się również w nakazie noszenia maseczek w miejscach publicznych, także wprowadzonym przez rozporządzenie ogłaszające stan pandemii. Jego podstawą miał być przepis ustawy o zapobieganiu oraz zwalczaniu zakażeń i chorób zakaźnych u ludzi, wskazujący że może zostać ustanowiony „obowiązek poddania się badaniom lekarskim oraz stosowaniu innych środków profilaktycznych przez osoby chore i podejrzane o zachorowanie" (Dz. U. z 2019 r., poz. 1239 ze zm., art. 46b pkt. 4). Przepis jednakże przekracza wyznaczone ramy, bowiem traktuje o obowiązku zakrywania twarzy przez wszystkich, niezależnie od stanu chorobowego. Nie sposób przyjąć tutaj wykładni rozszerzającej, nawet jeśli wirus COVID-19 może przebiegać bezobjawowo - chodzi bowiem o wolności i prawa jednostki, które $\mathrm{w}$ demokratycznym państwie prawnym powinny być ograniczane jedynie w ostateczności.

\section{KONSTATACJE}

Dokonując analizy krytycznej wybranych ograniczeń wprowadzonych przez decydentów w czasie pandemii, można wskazać szereg uchybień, takich jak: przekroczenie ustawowych upoważnień, wprowadzanie przepisów bez podstawy prawnej, a nade wszystko łamanie unormowań konstytucyjnych przy ingerencji w sferę wolności i praw człowieka i obywatela. Na łamach wywodu najpierw przedstawiono problematykę stanów nadzwyczajnych w polskiej Konstytucji, aby wskazać, jakie możliwości daje ustawa zasadnicza i jakie rozwiązania mogły być w tej sytuacji użyte. Warto zwrócić uwagę, że gdyby zdecydowano się na wprowadzenie stanu nadzwyczajnego, to mniej problemów nastręczałoby uregulowanie takich kwestii, jak ograniczenie wolności osobistej, wolności poruszania się i pobytu na terytorium Rzeczypospolitej czy prawa do wypoczynku. Nie podjęto takiej decyzji, ale pozostano w normalnym trybie 
funkcjonowania państwa, wprowadzając szereg rozwiązań doraźnych i wątpliwych z punktu widzenia systemowego.

Należy w tym miejscu zwrócić uwagę na kilka jeszcze kwestii przede wszystkim wprowadzenie stanu nadzwyczajnego w sytuacji pandemii nie tylko pozwoliłoby na uniknięcie wielu problemów prawnych, ale również pozytywnie wpłynęłoby na pewność społeczeństwa co do obowiązującego prawa. Unormowanie kwestii stanów nadzwyczajnych w Konstytucji ma na celu zapewnienie obywatelom pełnej świadomości, jakie ich prawa i na jak długi okres zostają ograniczone, a także poczucia, że „ich wolności i prawa nie staną się w określonych sytuacjach fikcja, a status RP jako demokratycznego państwa prawnego nie odejdzie do historii" (Bryk, 2011, s. 233). Na chwilę obecną część wprowadzonych obostrzeń wciąż obowiązuje bezterminowo - społeczeństwo żyje zatem w niepewności co do tego, jak długo jeszcze owe niekonstytucyjne ograniczenia ich wolności i praw będą przez państwo egzekwowane.

Jak słusznie zauważa RPO, mogą także nastąpić poważne problemy, jeśli chodzi o pociagganie do odpowiedzialności osób, które nie będą przestrzegały błędnie wprowadzonych zakazów i nakazów. Jest bowiem możliwe, że w takim wypadku obywatele, którzy zostaną ukarani, będą dochodzić swoich praw w sądach; podobnie zresztą może wyglądać kwestia osób, które na skutek wprowadzonych aktów prawnych poniosą szkodę - również oni będą najpewniej dochodzić swych praw, starając się uzyskać odszkodowanie od państwa polskiego (Bodnar, 2020, s. 9-10).

Na koniec warto jeszcze wspomnieć o problematyce związanej z obowiązującym Rzeczpospolitą prawem międzynarodowym. Zarówno bowiem Europejska Konwencja Praw Człowieka z 1950 roku (Dz. U. z 1993 r., nr 61, poz. 284; dalej: EKPCz), jak i Międzynarodowy Pakt Praw Obywatelskich i Politycznych z 1966 roku (Dz. U. z 1977 r., nr 38, poz. 167; dalej: MPPOiP) przewidują klauzule derogacyjne związane z czasowym uchyleniem się od stosowania praw i wolności gwarantowanych przez te akty w sytuacjach wyjątkowych dla państwa, kiedy istnieje niebezpieczeństwo dla narodu (Prokop, 2005, s. 124-131). W takim wypadku jednak, aby z takiej klauzuli derogacyjnej bez przeszkód skorzystać, państwo musi poinformować państwa-strony za pośrednictwem sekretarza generalnego ONZ (MPPOiP, art. 4, ust. 3) oraz „natychmiast” sekretarza generalnego Rady Europy 
Konstytucyjne możliwości ograniczania praw i wolności człowieka

(EKPCz, art. 15 ust. 3) o zastosowanych środkach, ich powodach oraz cezurze czasowej. Jak dotychczas Rzeczpospolita z tych zobowiązań się nie wywiązała, narażając się w przyszłości na oskarżenie o naruszenie podpisanych konwencji.

\section{Bibliografia}

Bodnar, A. (2020). Pismo do Prezesa Rady Ministrów (Sygn. pisma: VII.565.3.2020.ST/MM). Pozyskano z: https://www.rpo.gov.pl/ sites/default/files/Pismo\%20do\%20Prezesa\%20Rady\%20Ministr\%C3\%B3w.\%203.04.2020.pdf (dostęp: 29.07.2020).

Bryk, T. (2011). Przegląd regulacji stanów nadzwyczajnych w przepisach Konstytucji RP. Przeglad prawa konstytucyjnego, 1 (5). 223-234. Pozyskano z: https://marszalek.com.pl/przegladprawakonstytucyjnego/ ppk5/11.pdf (dostęp: 29.07.2020).

Konstytucja Rzeczypospolitej Polskiej z dnia 2 kwietnia 1997 roku (Dz. U. z 1997 r., nr 78 poz. 483).

Konwencja o Ochronie Praw Człowieka i Podstawowych Wolności sporządzona w Rzymie dnia 4 listopada 1950 r., zmieniona następnie Protokołami nr 3, 5 i 8 oraz uzupełniona Protokołem nr 2. (Dz. U. z 1993 r., nr 61 poz. 284).

Machowicz, K. (2009). Stany nadzwyczajne jako przesłanka legalnej ingerencji w prawa człowieka w Polsce. Zeszyty Naukowe Szkoły Głównej Straży Pożarnej, 38, (65-79). Pozyskano z: http://yadda.icm.edu.pl/yadda/element/bwmeta1.element.baztech-a67d0eeb-2fdc-4573-8985-cecb3b945603/c/65_pdfsam_ZN_SGSP_nr_38.pdf (dostęp: 29.07.2020).

Międzynarodowy Pakt Praw Obywatelskich i Politycznych otwarty do podpisu w Nowym Jorku dnia 19 grudnia 1966 r. (Dz. U. z 1977 r., nr 38 poz. 167).

Prokop, K. (2005). Stany nadzwyczajne w Konstytucji Rzeczypospolitej Polskiej z dnia 2 kwietnia 1997 r. (17-39, 123-139). Białystok: Temida 2. Pozyskano z: https://repozytorium.uwb.edu.pl/jspui/bitstream/11320/7138/3/K_Prokop_Stany_nadzwyczajne.pdf (dostęp: 29.07.2020).

Rozporządzenie Rady Ministrów z dnia 31 marca 2020 r. w sprawie ustanowienia określonych ograniczeń, nakazów i zakazów w związku z wystąpieniem stanu epidemii (Dz. U. z 2020 r., poz. 566).

Rozporządzenie w sprawie ogłoszenia na obszarze Rzeczypospolitej Polskiej stanu epidemii (Dz. U. z 2020 r., poz. 491; poz. 522; poz. 531). Sarnecki, P. (2008). Prawo konstytucyjne. Warszawa: C.H. Beck. 
Ustawa o lasach (Dz. U. z 1991 r., nr 101 poz. 444).

Ustawa o szczególnych rozwiązaniach związanych z zapobieganiem, przeciwdziałaniem i zwalczaniem COVID-19, innych chorób zakaźnych oraz wywołanych nimi sytuacji kryzysowych (Dz. U. z 2020 r., poz. 374).

Ustawa z 2008 roku o zapobieganiu oraz zwalczaniu zakażeń i chorób zakaźnych u ludzi (Dz. U. z 2019 r., poz. 1239 ze zm.).

WHO announces COVID-19 outbreak a pandemic. (2020). Pozyskano z: https://www.euro.who.int/en/health-topics/health-emergencies/coronavirus-covid-19/news/news/2020/3/who-announces-covid-19-outbreak-a-pandemic (dostęp: 29.07.2020).

\section{Copyright and License}

This article is published under the terms of the Creative Commons Attribution - NoDerivs (CC BY- ND 4.0) License http://creativecommons.org/licenses/by-nd/4.0/ 